\title{
Destruction hydrocephalus
}

\author{
その病態に対する一考察 \\ 中村 三郎·坪川 孝志
}

\section{Destruction Hydrocephalus}

Comments on its Pathophysiology and Case Report

\author{
Saburo Nakamura and Takashi Tsubokawa \\ Department of Neurological Surgery, Nihon University, Tokyo
}

\begin{abstract}
A case with hydrocephalus subsequent to neonatal intraventricular and intracerebral hemorrhages is reported. The hydrocephalus in this case was diagnosed to be obstructive due to subarachnoid hemorrhage. However, one lateral ventricle, in which intracerebral hemorrhage occurred, dilated predominantly compared with that in the contralateral hemisphere.

Hydrocephalus which occurs in the brain suffering from destructive changes due to some other causes than hydrocephalus, such as in this case, should be named "destruction hydrocephalus" as a new entity, and be discriminated from one which shows dilated ventricles simply due to increased intraventricular pressure. In this hydrocephalus, dilatation of the ventricle occurs irregularly and relatively in short periods, causing secondary cerebral destruction. Therefore, ventriculostomy to prevent progression of cerebral damage is required as soon as possible.
\end{abstract}

Key words: hydrocephalus, neonate, intraventricular hemorrhage, intracerebral hemorrhage

\section{I はじめに}

水頭症における脳军搪大の機序についてはなお十分解明 されない点があるが，脳室系の bulk flow が㜔害された場 合，障害部位より側脳突側の全脳空が拡火することは周知 の事実である゙．すなわち，㵦液の back pressure が脳室壁 に作用し，脳空壁がこの圧炕よって一次的に，また CSF edemaのご上き脳夷質の焫態発牛2,8.12.13.17.21 に続いて 二次的に应大寸ることが考えられている。この際，脳室壁 老構成する組織や形状の相湋から各脳室の执大は均等に生 じないが，交通性水頭症または第三脎室以下の閉塞では一 般に左右側兴室は対称的に拡大寸る。
今回, 水頭抔病態の発生後, 単に正常脳室壁に檤液の back pressureが加わることによって脸室が应大したもの ではなく，水頭症病態発生に先行した脳室壁の病変のため に不規則で顕著な脳室昖大を呈した水頭症の存在を認め， 特異な水頭泟として検卻を加えた。

\section{II 症例}

<患者> 4 力月，女㫛

主訴：異常頭围拡大

現病歴：妊娠歴に特記事項なく，在胎26週 5 日で分娩々 なった。出生体重 $1,112 \mathrm{~g}$, Apgar score 3 点で, 特発性呼 吸笨迫症候群と診断され，新生児集中治療空で管理され

月本大学脳神経外科

Address reprint reguests to: S. Nakamura, M.D., Department of Neurological Surgery, Nihon University, 30-1 Oyaguchi-kamimachi, Itabashi-ku, Tokyo 173

受稿 1984年11月28日受理 1985年3月 5 日 
た、日齢 1 に扔いて自発運動の障害，刺激に対寸るイ榣上 心などがみられ，また人泉門の浲度膨隆を認めたため腰椎。 穿刺が拖行され，血性能液が挀明された。同口行ったCT で东側脳室の著しい抬大老伴う脳室队出血，左前韻葉およ

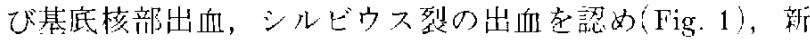

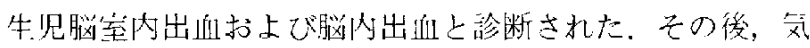
管内挿管による呼吸管理，輸液，輸血による偱罢・体液管 玾によりしだいに vital signは改善され，日龌24のCTで

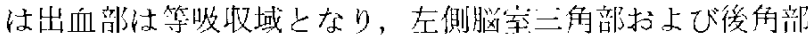
は低吸収值を示していた(Fig. 2A)。ところがH撂29比上 り人泉門の膨降，嘔叶が歹られ，日齢39䫉上り頭囲の急速

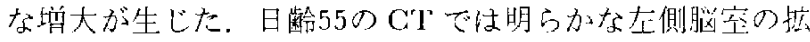

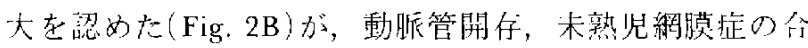

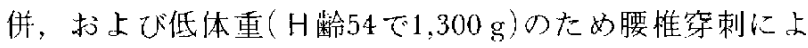
る眙液の排除が連巨施行さ扎た。しかし，脳室拡大こと に左側兴室の昖大がさらに著しくなり(Fig. 2C)，また vital sign が交定し，体重增加毛みら机，日噛139に㧍いて 当科站斿龙。

入院時所見: 身長 $56.0 \mathrm{~cm}$, 頭囲 $44.0 \mathrm{~cm}$, 胸囲 $36.5 \mathrm{~cm}$, 体重 $4,058 \mathrm{~g}$ であり，哳乳良好で一日攝取星は680 $\mathrm{m} /$ であ

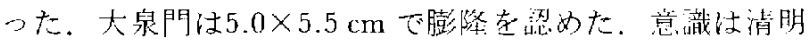
であるが落陽現象陽珄，Macewen 徵候陽性で，首のすわ りは不主であった。四肢の自発運動には左右差なく，わず

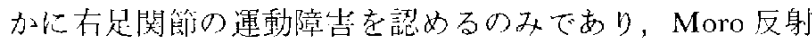
は䧄性:であった。

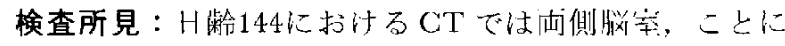

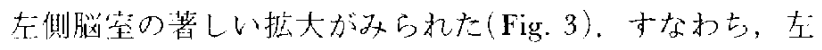

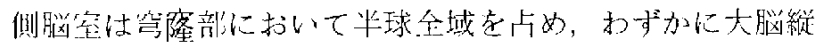

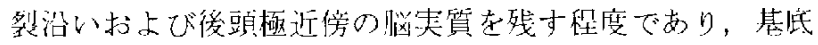

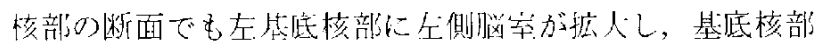

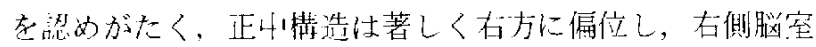

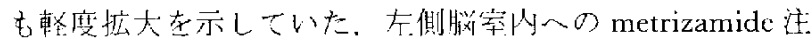
人ては造影剂が右側脳空に移行し，左石突間孔の開乍を示

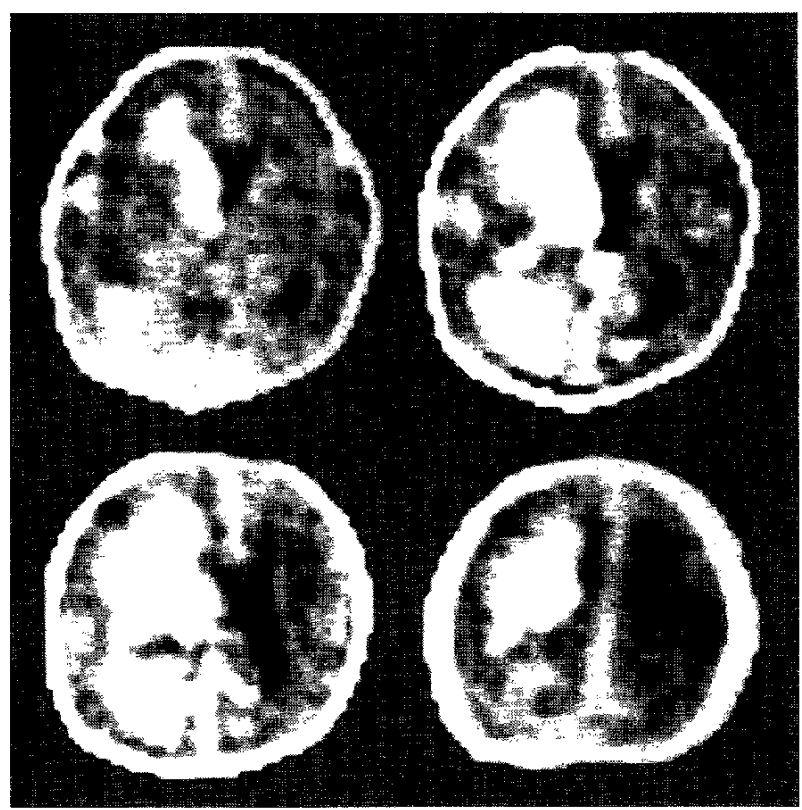

Fig. I Initial plain computed tomography (CT) scan 1 day after birth revealing a large intracerebral hemorrhage in the left hemisphere and intraventricular hemorrhage.
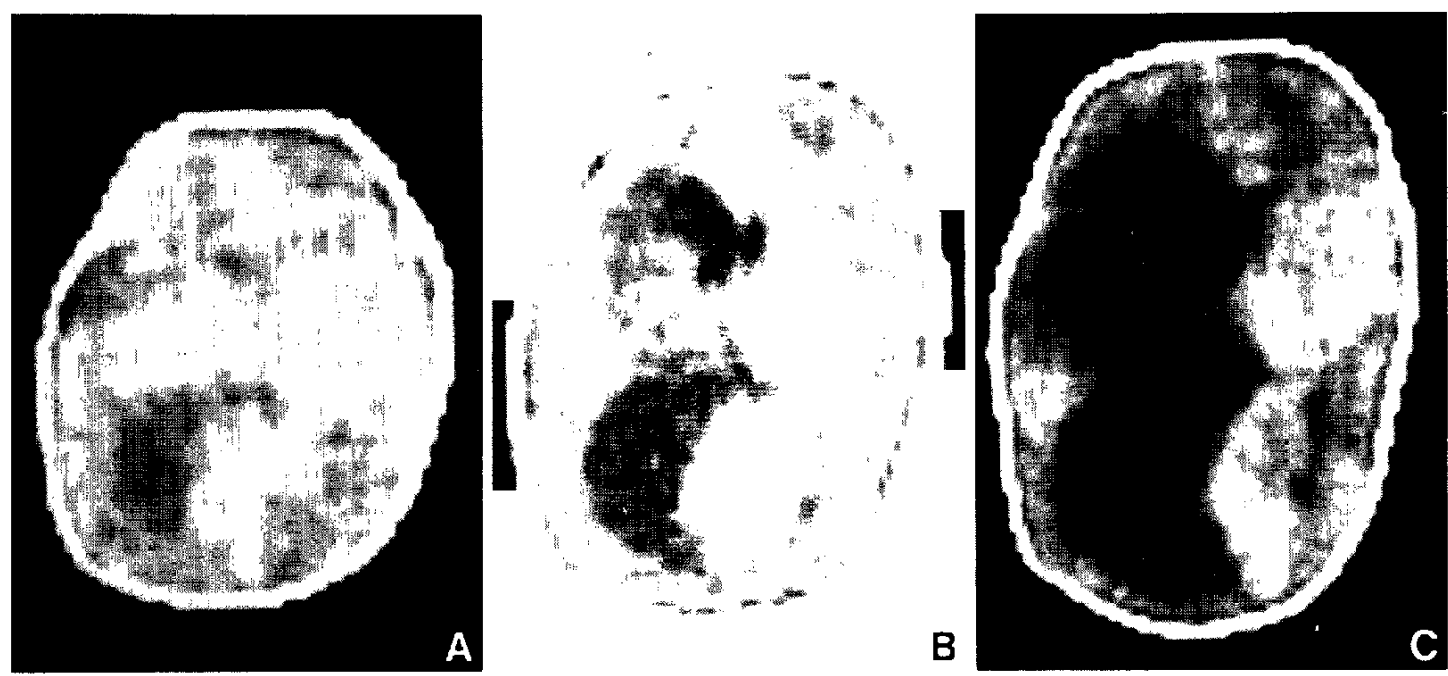

Fig. 2 A: Plain CT scan on day 24 revealing a lowered densicy of hemorrhage. B: Plain CT scan on day 55 revealing a slightly dilated left lateral ventricle. C: Plain CT scan on day 98 revealing the significantly dilated left lateral ventricle. 

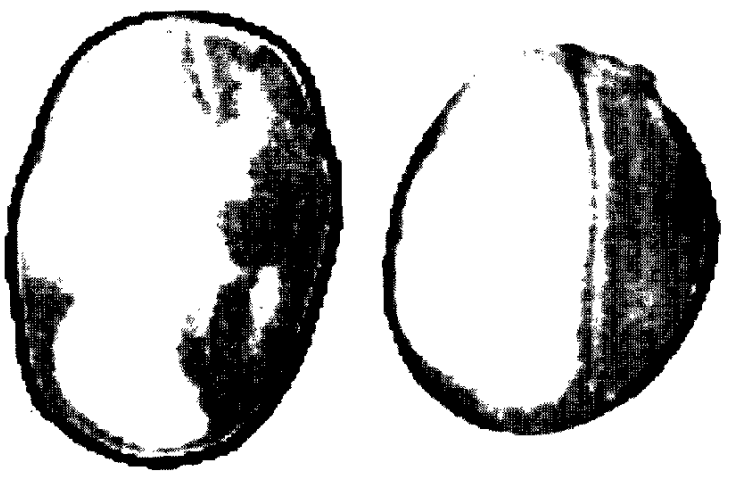

Fig. 3 Plain CT scan on day 144 revealing a extremely dilated left lateral ventricle and slightly enlarged right lateral ventricle.

していた(Fig. 4). 一)j, ${ }^{131} \mathrm{I}$-human serum albumin $\left({ }^{131} \mathrm{I}-\right.$

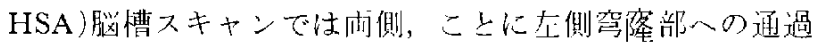
障害が示された(Fig，5)。

臨床経過：日齢153に打いてDenver吻合管による在側

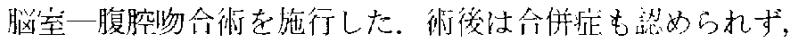
8 日HのCT で闩側脳室の維小が垫められた(Fig. 6A)。こ とに左側半球ではすでに左前蛽葉に㧍ける mantle の增幅 が生じて抢り，正中梅造の偏位も軽減していた。頙国は手 術当日 $44.7 \mathrm{~cm}$ であったものが術俊3日で $43.5 \mathrm{~cm}, 14$ 日で

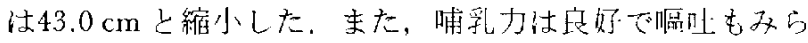
れず，全身状態是好にて術後 $20 \mathrm{H}$ 軽快泿院した。

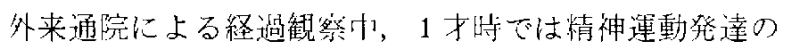

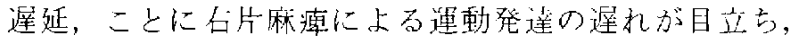
developmental quotient (DQ)は63.3であった。術媛 1 年 6
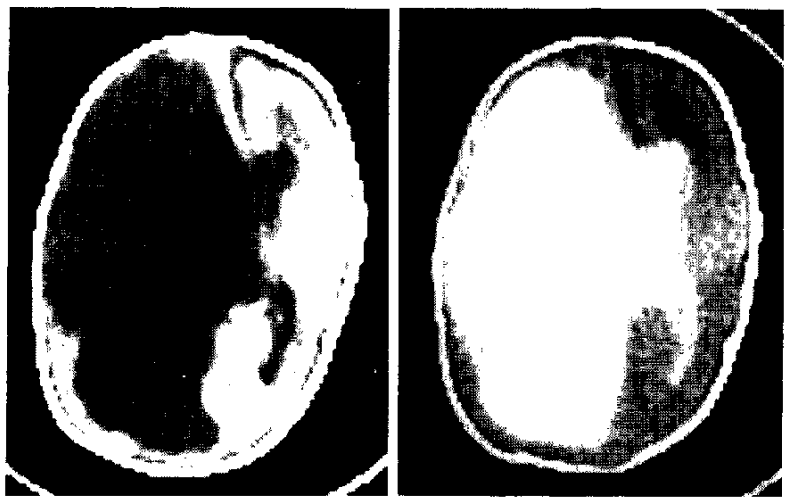

Fig. 4 CT scan before (left) and after (right) metrizamide ventriculography. An opening of the interventricular foramina can be seen.
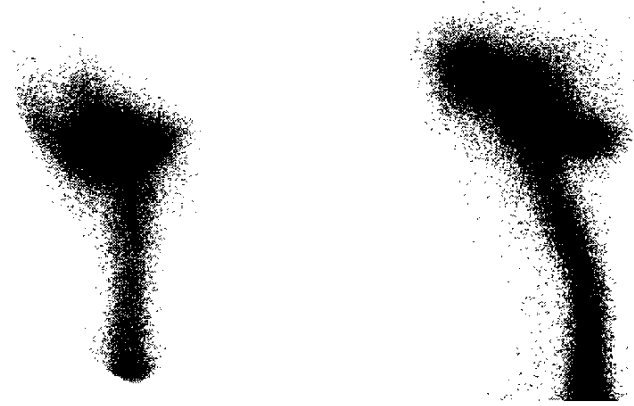

A
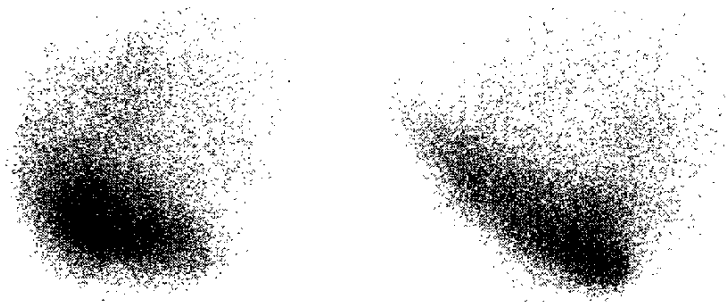

B

Fig. 5 A: Cisternograms 2 hours after injection of ${ }^{131}$ I-human serurn albumin (131 I-HSA), anteroposterior (left) and lateral (right) vicws, showing asymmetrical passage of the tracer. B: Cisternograms 24 hours after injection of 131-HSA, antcropostcrior (left) and lateral (night) views, showing a blockage of the subarachnoid space.
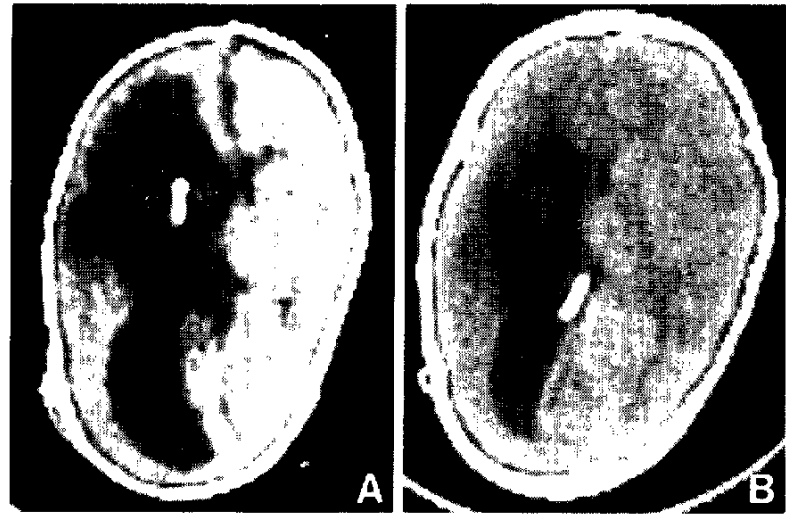

Fig. 6 A: Postoperative CT scan 8 days after shunt operation demonstrates a slight decrease of the ventricular size. $B: C T \operatorname{scan} 18$ months after the operation reveals a thickening of the ccrebral mantle of the left hemisphere. 
力月（月歯23）におけるCTでは左大脳半球全体の発達に伴 って mantleの增大がみられ，また左侧脳辮は著しく樎小 していたが，前角部，体部にかけて不挸則な摭大が残存し

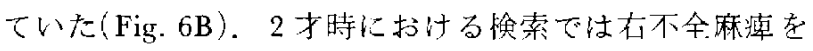
認め，DQ44.6上精神運動発達遅延がみられた。

\section{III 考察}

本症例は新牛児細室内出近に水頭症が続発したものであ る。新生児脳室内出血後の水頭症の発牛について, Krishnamoorthy $ら^{6}$ は新生児脳室队出血の㠿存例15例中 8 例に兴室应大が生じ，このうち脳室吻合術を必要としたの

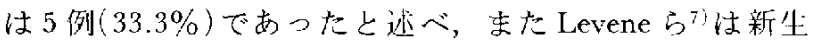
罗脳室内出血の生存例 39 例中 3 例 $(7.6 \%)$ ) 奴浽室吻命

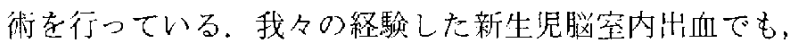
牛. 存例 7 例中 2 例 $(28.5 \%)$ に脳室吻合術が施行されてい $る^{14)}$ 。これらの水頭症は，脳䇪内出血に続発したクモ膜下 出血によりクモ膜ド腔の䦌基が生じた閉塞性水頙佂である 埸合が多いと考えられる。本将例の場合も， ${ }^{131} \mathrm{I}-\mathrm{HSA}$ 兴 槽スキャンの所見はクモ膜下腔の閉塞を示唆していた。

一般的に，クモ膜下覀閉塞在因とした閉塞性水頭莎に

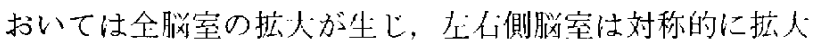
寸る。しかし，本捗例に扔いては右側脳公む抬大している ものの左側脳空は左人脸半球のほぼ全域を占めるほどに拉 大し，著しく非対称的な水頭证であったこの上うな非赫 称的な側脳室の拡大を示す水頭症をDott" hydrocephalus”と呼称し，一側室间孔(Monro孔)の闭塞 老原风としている。本疗例に㧊いては， metrizamide脳室 造影で明らかなごとく室間孔の閉塞は認めていない。

水頭掟の治療上して脳公吻合術が行われた場合，脳窒は 縮小傾向を示寸．ことに小児ではその傾向が顕茪である が，側脳安の縮小様式は左右で，または前角と後角上で縮 小速度が異なる場合もあって，一様な縮小をきたさない证

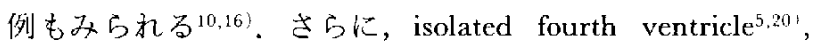
isolated unilateral hydrocephalus ${ }^{19}$ といった病態では脳室吻 合術後，脳室の部分的搥大が残存する24)こと孛特徽上して いる。本定例に扔いても脳案吻合術後左側脳室の拉大が残 存したが，術後 1 年 6 力月のCT では左側脳室の粳小がみ られており, isolated unilateral hydrocephalus と買なるこ とは術前の脳室选影所見からも明らかである。

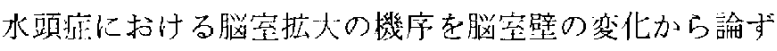
る報告がみられる。才なわら，水頭症における兴空壁の变 化として脳室上衣の断裂11,22!，上衣下層の浮腫状変化 ${ }^{22,23 !}$ などが登げられて㧍り，前者は ependymal splitting，徭者 は subependymal spongy state るいい CSF edema と呼ば れる状態である。これらの変化は，䯣液圧方進による back pressure の作用による単純な物理的病変に加えて脳

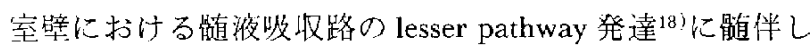
た病変としての二次的脸損傷である。一方, 我々は脳室内 压負荷時に扔ける脳空壁の变化を負荷厉との関連で㛟討し た結果, 比挍的低圧で最初に变化が出現寸るのは上衣下原 であり，上花細胞は75 $\mathrm{mmHg} ， 1$ 時間の負荷に耐えるこ上

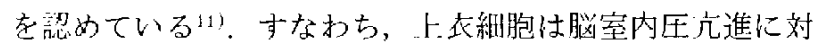
し比較的高い耐容性去小ず代下層の耐容性は低く，ま た上衣細泡の splitting は上衣卜層側より始まっていること から, ependymal splitting は上卡層の变化に誘発されて 二次的に生ずることが賽われる、いずれにしても，このよ うな上花細胞および上衣下層の病変は脳案壁の compliance 在高め，脳空摭大を莣起すると考えられる。

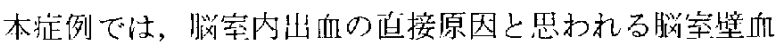
行障害(主として静脈系)によって脳室周囲の敛実質内に出 血を伴う脳組織の損傷が脳室内出向と同時期に発生、したこ とが窅われる。すなわち，この一次的な脸組織の撌傷によ つて脳先質の compliance 加増加し，これに水頭症の病態 が加わったこにによって著しい脳室掘大をきたしたもので あるう，ちなみに，脳実質の損伤が生じなかった右倒脳室 ではごく軽度の脳室拉人を示したにすぎない，我々は，本 症例のごとく水頭症病態と注別の原因による一次的脳損甥 合併した水頭症を“destruction hydrocephalus”' と命名 し，脳公内圧元進のみによって脳室拉人をきたす水頭症と は別の将患単位として区别することを提唱する。

Destruction hydrocephalus と他疾患との成連に抬いて， まず“dysgenetic hydrocephalus”(Benda)”または“hydroencephalodysplasia”, 15! 在取り上げてみると, 病態が完成し た状態ではこれらと大変近似のものである場合が考えられ る。すなわち，後二者に招いても血液循璦障害その他原因 不明の一次的な脳組織障㗉が水頭抂病態に先行，または同 時に発生した垬合にはまったく同一の病態である。しか し, 根本的な相違仙後二者では出生前の脳形成過程に扔い

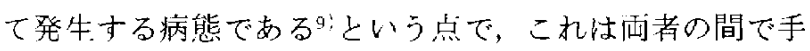
術適応揖上び予後に大きな差をむたらすことが考えられ る。また，孔脳佂との関倸についてみると, destruction hydrocephalusに护省脳の一次的損傷そのものは孔脳症 に発展寸る可能性があると考えられる。しかし，本症では 水頙症が加わっている点で異なり，しかも適切な治療が行 われない場命には水頭挍の病態によって脳損傷を伴う脳室 摭人が急速に進行する現彖は大变特異な点である。なお， 本水頭症は一次的脳損傷の発牛部位によって脳室拡大の形 態が異なり，雨側大兴半球に一次的脳損傷が発生した場合 には付側性の脳空拈大を生ずることが考えられる，本症例 では、次的脳損傷が一側半球に生じたため，あたかも uni- 
lateral hydrocephalus のごとき形態を呈したにすぎない.

Destruction hydrocephalus の予後は訤実質内出南による 一次的脳損傷の程度によって大きな影響を受けるが，水頭 症病態の改善が行われない場合に汇合併する咉液偱環障害 がもたらす艏液の back pressureによって二次的脸損榎が 進行し，予後をいっそう悪化する。したがって，本症に刘 しては可及的速やかに兴去吻合術在行い， 次的脳損傷の 修復を促進し，一次的脳椇傷の発生を最少限に留めること が肝要である。

\section{IV 結 語}

新生少脑室內出血後に発生した水䫈症例に対し“destruction hydrocephalus"とい5新しい疾患単位を提昌したが, 一次的脳損傷として本症例のごとき出血以外に外傷，炎 症，扩上ひ偱環障書など多くの病態が水顛症病態に先行し た場合にも本症が発生しうるもの上考察する。さらに，成 人に打いても本拝の発特があるものと考光られ，今後広く 検討を行ってみたい.

\section{文献}

1) Benda CE: The Dandy-Walker syndrome or the so-called atresia of the foramen Magendie. I Neurapath Exp Neurol 13: 1429,1954

2) Clark RG, Milhorat TH: Experimental hydrocephalus. Part 3: Light microscopic findings in acute and subacute obstructive hydrocephalus in the monkey. J Neurosurg 32: 400-413, 1970

3) Dandy WE, Blackfan KD: Internal hydrocephalus. An experimental, clinical and pathological study. Amer $\int$ Dis Child 8: 406-482, 1914

4) Dott NM: A case of left unilateral hydrocephalus in an infant. Operation-cure. Brain 50: 548-561, 1927

5) Hawkins JC III, Hoffman HJ, Humphreys RP: Isolated fourth ventricle as a complication of ventricular shunting. Report of three cases. I Neurosurg 49: 910-913, 1978

6) Krishnamoorthy KS, Shannon DC, Delong GR, Todres ID, Davis KR: Neurologic sequelae in the survivors of neonatal intraventricular hemorrhage. Pediatrics 64: 233-237, 1979

7) Levene MI, Starte DR: A longitudinal study of post-haemorrhagic ventricular dilatation in the newborn. Arch Dis Child 56 : $905-910,1981$

8）森安信雄，中村三郎，宮上光㳓：水頡症に打忊子脳室上走 の形態学的研究，小児の脳神 1: 35-46, 1976

9）村上坄広：中枢神経系奇形の成立機序上遺伝，神研の進步
8: $394-416,1964$

10）中村三郎，古賀信憲，坪川孝志，森安信雄：水頭症におり る shunt術後の脳扝よび脸室の変化. CT 研究 2:45-51，1980

11）中村三郎，森安信维，片㭣丈之：脳室内負荷几扔ける初期

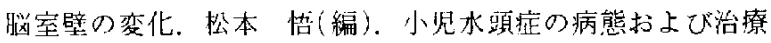
(1983)。果京，に中一ろん社，1983，pp 7-16

12）中村三郎，一井美行，中村晢三，森安信堆：尧駽的水頭泟

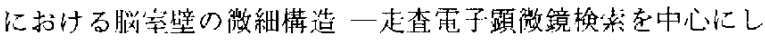
て一。脳と神 25: 1583-1599, 1973

13）中村三郎，大井美行，中村哲三，坪川孝志，森安信雄：㓱

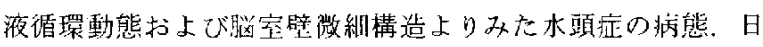
外会誌 75: 265-268, 1974

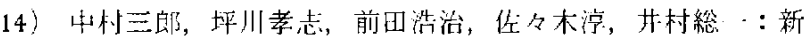
生先頭蓋内出血，特に脸等内出向 $の$ 病態と対策。日大医誌 43: 263-271, 1984

15) Picaza JA, Cardelle G, Timenz M: Hydroencephalodysplasia: An anatomico-clinical picture. $J$ Neurosurg 12: 535-549, 1955

16) Rubin RC, Hochwald GM, Tiell M, Epstein F, Ghatak N, Wisniewski $\mathrm{H}$ : Hydrocephalus: III. Reconstitution of the cerebral cortical mantle following ventricular shunting. Surg Neurol 5: 179183,1976

17) Rubin RC, Hochwald GM, Tiell M, Mizutani H, Ghatak N: Hydrocephalus: I. Histological and ultrastructural changes in the pre-shunted cortical mantle. Surg Neurol 5: 109-114, 1976

18) Sahar A, Hochwald GM, Ransohoff J: Alternate pathway for cerebrospinal fluid absorption in animals with experimental obstructive hydrocephalus. Exp Neurol 25: 200-206, 1969

19) Salmon JH: Isolated unilateral hydrocephalus following ventriculoatrial shunt. $J$ Neurosurg 32: 219-226, 1970

20) Scotti G, Musgrave MA, Fitz CR, Harwood-Nash DG: The isolated fourth ventricle in children: $\mathrm{CT}$ and clinical review of 16 cases. AJR 135: 1233-1238, 1980

21) Weller RO, Shulman K: Infantile hydrocephalus. Clinical, histological and ultrastructural study of brain damage. $J$ Neurosurg 36: $255-265,1972$

22) Weller RO, Wisniewski $\mathrm{H}$ : Histological and ultrastructural changes with experimental hydrocephalus in adult rabbits. Brain 92: $891-928,1969$

23) Wisniewski H, Weller RO, Terry RD: Experimental hydrocephalus produced by the subarachnoid infusion of silicone oil. I Neurosurg 31: 10-14, 1969

24) Zimmerman RA, Bilaniuk LT, Gallo E: Computed tomography of trapped fourth ventricle. $A J R$ 130: 503-506, 1978

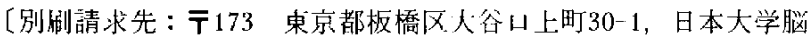
神経外科，中村三郎] 